\title{
Pelatihan penggunaan aplikasi alat ungkap masalah (AUM) PTSDL SERI SLTP untuk pemetaan masalah belajar siswa
}

\author{
${ }^{*}$, Riska Andriani ${ }^{2}$, Maria Oktasari \\ ${ }^{12}$ Bimbingan dan Konseling, Fakultas Ilmu Pendidikan dan Pengetahuan Sosial, Universitas \\ Indraprasta PGRI Jakarta, Indonesia \\ *Corresponding author, riskaandriani366@gmail.com
}

$\begin{array}{ccc}\text { First received: } & \text { Revised: } & \text { Final Accepted: } \\ 24 \text { Agustus } 2021 & 31 \text { Agustus } & 19 \text { Oktober } 2021\end{array}$

\begin{abstract}
Abstrak
Asesmen merupakan kegiatan yang sangat penting untuk dilakukan oleh Guru BK karena hasil asesmen dijadikan sebagai landasan dalam pembuatan program BKy ang sesuai dengan kebutuhan siswa. Artinya asesmen dilakukan untuk mengetahui apa kebutuhan dan bagaimana kondisi siswa. Salah satu instrumen y ang dapat digunakan adalah AUMPTSDL. Namun, ada beberapa hambatan yang dihadapi oleh Guru BK ketika melakukan asesmen, salah satunya pengolahan hasil assemen memerlukan waktu yang lama. Hal ini dikarenakan masih terbatasnya kemampuan dalam melakukan pengolahan data hasil assesmen secara komputerisasi. Tujuan kegiatan abdimas adalah memberikan pelatihan kepada guru BKSMP N 17 Depok tentang penggunaan aplikasi AUM PTSDL Seri SLTP dalam mengolah hasil assemen. Metode pelatihan y ang digunakan adalah ceramah, tanyajawab, dan praktik. Kegiatan pelatihan ini diikuti oleh guru BK SMP N 17 Depok yang berjumlah 3 orang. Hasil pengabdian ini adalah bertambahnya pengetahuan dan kemampuan guru BK dalam menggunakan AUM PTSDL Seri SLTP secara komputerisasi.

Kata Kunci: AUM PTSDL, As es men, Guru BK
\end{abstract}

\begin{abstract}
Assessment was a very important activity to be done by counseling teacher because the assessment results are used as a foundation in the creation of counseling programs that are in accordance with the needs of students. This means that assessment was done to find out what the needs and how the condition of the student. One of the instruments that can be used is AUM PTSDL. However, There are several problems experienced by counseling teachers when conducting assessments. One of which was the processing of assemen results takes a long time. This is because counseling teachers have limited ability to process the results of computerized data assessments. The purpose of abdimas activities $i$ to provide training to counseling teachers of SMP N 17 Depok about the use of AUM PTSDL Series SLTP applications in processing assemen results. The training methods used are lectures, Question $\&$ Answer, and practice. This training activity was attended by counseling teachers of SMP N 17 Depok who numbered 3 people. The study was the increasing knowledge and ability of counseling teachers in using AUM PTSDL Series SLTP computerized.
\end{abstract}

Keywords: AUM PTSDL, Assesment, Counseling Teacher 


\section{PENDAHULUAN}

Pandemi covid 19 sampai saat ini masih belum berakhir, banyak dampak yang ditimbulkan dari terjadinya pandemi ini. Tidak terkecuali dalam dunia pendidikan. Sistem pembelajaran yang tadinya offline berubah menjadi online (Kemendikbud, 2020). Perubahan sistem pembelajaran ini menimbulkan masalah-masalah baru, antara lain: keterbatasan sumber daya manusia, keterbatasan sarana dan prasarana, seperti: Laptop atau Handphone yang dimiliki siswa, keterbatasan kuota internet (Mukhlison, 2020). Permasalahan tersebut tidak hanya dialami oleh siswa tetapi guru pun merasakan hal yang sama, salah satunya guru bimbingan dan konseling (Guru BK). Kendala yang dialami oleh guru BK selama pembelajaran online salah satunya adalah terkait dengan pelaksanaan asesmen di sekolah (Tere \& Herdi, 2021).

Asesmen merupakan salah satu hal yang penting untuk dilakukan oleh guru BK. Gibson dan Mitchel (2008) menjelaskan bahwa asesmen merupakan dasar dari pengembangan program yang akuntabel. Asesmen menjadi kunci bagi kesuksesan perencanaan program bimbingan dan konseling yang dibuat, dan kegiatan asesmen lebih difokuskan pada pencarian fakta, sehingga kegiatan layanan yang dilakukan sesuai dengan kondisi nyata siswa. Sejalan dengan pendapat Komalasari \& Wahyuni (2011) pelaksanaan asesmen bertujuan untuk mengetahui bagaimana kondisi diri peserta didik dan kondisi lingkungannya. Hasil asesmen yang didapatkan digunakan sebagai dasar untuk membuat perencanaan program, pemberian konseling, atau memberikan layanan yang tepat bagi siswa. Namun, berdasarkan hasil studi pendahuluan yang dilakukan tim abdimas beberapa hambatan yang ditemui oleh guru BK di Sekolah Menengah Pertama Negeri (SMP N) 17 Depok saat melakukan asesmen, yaitu: 1) keterbatasan waktu dalam melalukan asesmen, 2) keterbatasan dalam menggunakan teknologi/ aplikasi AUM PTSDL 4) Sistem pembelajaran online sehingga memerlukan penyesuaian terhadap instrumen yang digunakan untuk asesmen, 5) keterbatasan guru BK dalam mengolah, menganalisis dan menginterpretasi data yang didapatkan dari hasil instrumen.

Sejalan dengan hasil temuan penelitian terdahulu antara lain: jika pelaksanaan asesmen dilakukan secara manual maka akan membutuhkan waktu yang lama, mulai dari proses penginputan data sampai dengan interpretasi data (Imawanty, \& Fransiska, 2019). Selanjutnya, ketidakseimbangan rasio tenaga konselor dengan siswa yang dilayani menimbulkan kendala tersendiri bagi konselor dalam melakukan asesmen kebutuhan siswa (Tere \& Herdi, 2021). Lebih lanjut, besarnya waktu dan tenaga yang dihadapkan dengan keadaan BK disekolah yang belum ideal, tidak sedikit konselor memilih mengesampingkan kegiatan asesmen kebutuhan sehingga program layanan yang diberikan oleh konselor sering kali salah sasaran/ kurang tepat sehingga menimbulkan dampak, bahwa layanan dianggap kurang penting oleh siswa (Sukma Hanggara et al., 2018; Tere \& Herdi, 2021). Selain itu, biasanya pelaksanaan asesemen dilakukan secara offline namun ketika pembelajaran online berlangsung ini menjadi tantangan tersendiri bagi Guru BK dalam melaksanakan asesmen. Guru BK dituntut untuk menguasi teknologi untuk dapat melaksanakan asesmen kebutuhan siswa secara online (Hatch \& McCarthy, 2003; Ifdil et al., 2017; Stevani et al., 2019). Namun, faktanya guru BK masih memiliki kemampuan yang terbatas dalam melakukan asesmen kebutuhan secara online (Saman et al., 2020). Idealnya guru BK harus mampu menggunakan media informasi 
sebagai alat bantu dalam menjalankan tugasnya, Seperti: Aplikasi Komputerisasi Alat Ungkap Masalah (AUM) PTSDL (Evianti et al., 2020).

Permasalahan di atas, menjadi dasar tim pengabdian masyarakat untuk melaksanakan kegiatan pengabdian masyarakat. Kegiatan abdimas yang akan dilakukan adalah dengan memberikan pelatihan penggunaan aplikasi AUM PTSDL Seri SLTP untuk memetakan permasalahan belajar siswa. Ada beberapa Instrumen yang dapat digunakan dalam pelaksanaan asesmen dalam bimbingan dan konseling baik instrumen non tes ataupun tes. Namun, dalam pelaksanaan Abdimas ini berfokus hanya pada satu instrumen yaitu: Aplikasi AUM PTSDL Seri SLTP. Instrumen AUM PTSDL ini bertujuan untuk mengetahui permasalahan belajar yang dialami siswa.

Mitra dalam kegiatan abdimas ini adalah Sekolah Menengah Pertama Negeri 17 Depok. Sasaran kegiatan adalah Guru BK dan Siswa. Mitra dianggap tepat dikarenakan untuk melaksanakan pelayanan BK yang tepat perlu pengembangan diri dari guru BK sehingga kompetensi profesional guru BK meningkat, secara khusus dalam menggunakan aplikasi instrumentasi (AUM PTSDL).

\section{METODE}

Metode yang digunakan dalam pelaksanaan abdimas ini adalah dengan memberikan pelatihan kepada guru BK. Pelatihan disampaikan dalam bentuk ceramah tentang AUM PTSDL (Hussain et al., 2011), tanya jawab terkait dengan materi AUM PTSDL (Awaluddin, 2019) dan praktik/latihan penggunaan aplikasi komputerisasi AUM PTSDL (Lestari et al., 2017) . Aplikasi Komputerisasi yang digunakan adalah aplikasi yang dibuat oleh Drs. H. Mastur, M.Pd., Kons.

Adapaun tahapan dalam pelaksanaan kegiatan abdimas ini terbagi dalam beberapa tahapan, yaitu:

\section{Tahap Persiapan}

Ada beberapa hal yang dilakukan oleh tim abdimas dalam tahap persiapan, yaitu: a) penentuan tempat dan waktu pelaksanaan, b) penentuan pengisi materi abdimas, c) pembuatan materi pelatihan, d) menyiapkan aplikasi zoom sebagai wadah pemberian pelatihan.

\section{Tahap Pelaksanaan}

Tim abdimas melaksanakan kegiatan abdimas sesuai dengan yang telah disusun dalam rundown kegiatan. Berikut secara lengkap dijelaskan pada Tabel 1.

Tabel 1

Rundown Kegiatan Abdimas

\begin{tabular}{lcl}
\hline \multicolumn{1}{c}{ Nama Kegiatan } & Waktu & \multicolumn{1}{c}{ PJ Kegiatan } \\
\hline Pembukaan oleh MC & $10.00-10.15$ & MC (Vio Hernawati) \\
$\begin{array}{l}\text { Sambutan ketua abdimas } \\
\text { Sambutan Koordinator BK SMP }\end{array}$ & & $\begin{array}{l}\text { Riska Andriani, M.Pd. } \\
\text { Suhartiningsih, S.Pd. }\end{array}$ \\
\hline $\begin{array}{l}\text { Pepok } \\
\text { Mengampaian Materi }\end{array}$ & \\
\hline
\end{tabular}




\begin{tabular}{llll}
\hline Penggunaan Aplikasi & AUM & & \\
PTSDL (Praktik) & & $09.00-12.00 \quad$ Maria Oktasari, M.Pd.
\end{tabular}

\begin{tabular}{lll}
\hline Penutup & 12.00 & MC (Vio Hernawati) \\
\hline Tahap Evaluasi Kegiatan &
\end{tabular}

Tahap Evaluasi Kegiatan

Pada tahap ini tim abdimas melakukan evaluasi terhadap kegiatan yang sudah dilaksanakan untuk melihat keberhasilan dan kekurangan pelatihan yang telah dilaksanakan. Evaluasi dilakukan dengan memberikan pertanyaan terkait dengan materi yang dilatihkan.

\section{HASIL DAN PEMBAHASAN}

Kegiatan abdimas dilaksanakan pada hari Kamis, 15 Juli 2021, jam 10.00-12.00 melalui aplikasi zoom meeting. Peserta dalam kegiatan ini adalah Guru Bimbingan dan Konseling (BK) SMP Negeri 17 Depok sebanyak tiga orang. Kegiatan terbagi menjadi dua sesi, sesi 1 penyampaian materi tentang teori dari AUM PTSDL Seri SLTP yang disampaikan oleh ibu Riska Andriani, M.Pd.

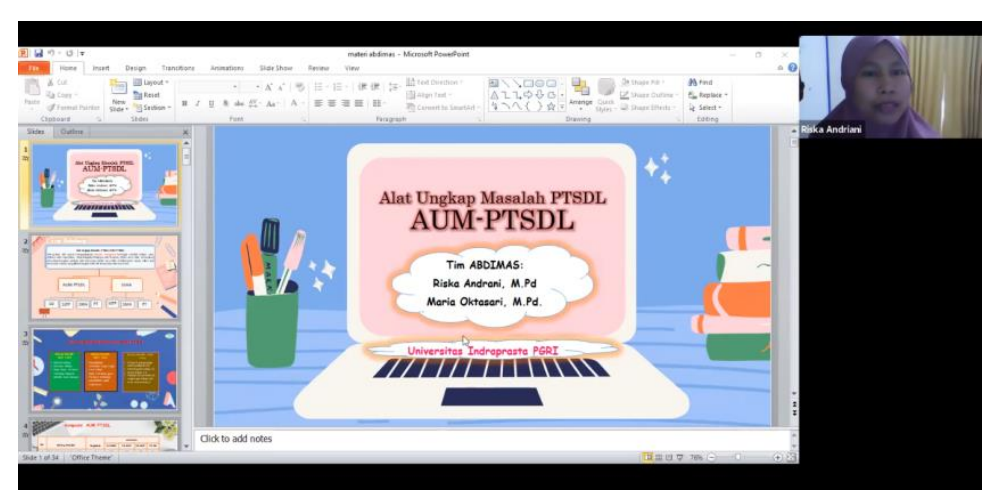

\section{Gambar 1}

Penyampaian Materi 1

Kemudian sesi 2 dilanjutkan dengan materi praktik pengolahan AUM PTSDL Secara Komputerisasi yang disampaikan oleh ibu Maria Oktasari, M.Pd.

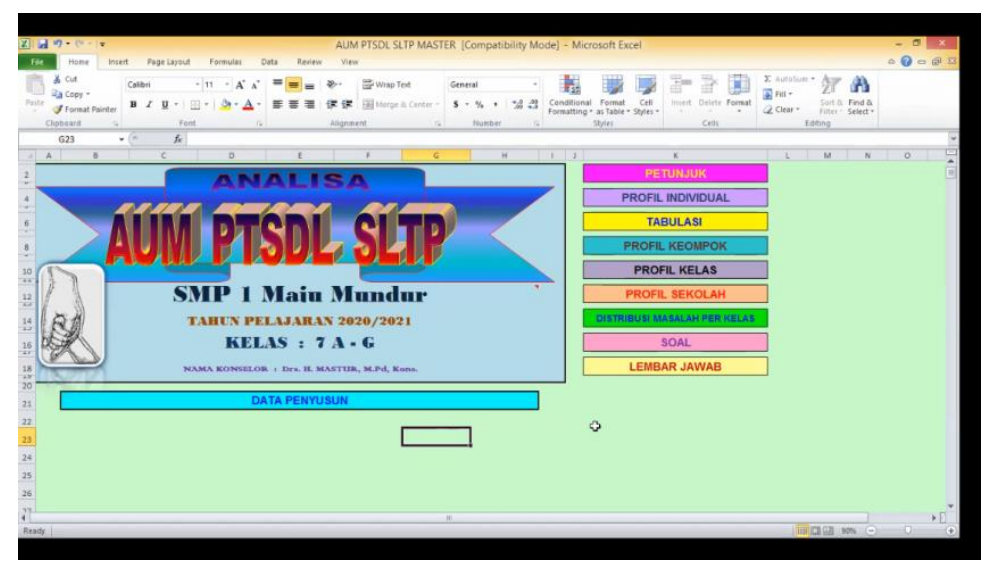

Gambar 2

Penyampaian Materi 2 
Hasil dari pemberian beberapa pertanyaan yang diajukan terkait materi layanan yang telah diberikan, sebagai berikut.

Tabel 1

Gambaran Kondisi Sebelum dan Sesudah Pelatihan

\begin{tabular}{|c|c|c|c|}
\hline No. & Nama & Sebelum Pelatihan & Sesudah Pelatihan \\
\hline 1. & S & $\begin{array}{l}\text { Ketika melakukan need assessment, } \\
\text { belum pernah menggunakan AUM } \\
\text { PTSDL dan belum mengetahui } \\
\text { bagaimana pengolahan AUM PTSDL } \\
\text { menggunakan aplikasi komputer. }\end{array}$ & $\begin{array}{l}\text { mengetahui dan mampu } \\
\text { mempraktikkan } \\
\text { pengolahan AUM PTSDL } \\
\text { menggunakan aplikasi } \\
\text { komputer. }\end{array}$ \\
\hline 2. & $\mathrm{RN}$ & $\begin{array}{l}\text { Sudah mengetahui bahwa dalam } \\
\text { pengolahan AUM PTSDL bisa } \\
\text { menggunakan aplikasi komputer, } \\
\text { namun belum mengerti dan paham } \\
\text { menggunakannya. } \\
\text { Selain itu, tidak memiliki aplikasi } \\
\text { secara komputerisasi sehingga masih } \\
\text { melakukan pengolahan secara manual }\end{array}$ & $\begin{array}{lr}\text { Mengerti dan } & \text { mampu } \\
\text { mempraktikkan } & \\
\text { bagaimana } & \text { cara } \\
\text { pengolahan AUM PTSDL } \\
\text { menggunakan aplikasi } \\
\text { computer. }\end{array}$ \\
\hline 3. & AT & $\begin{array}{l}\text { Secara teoretis sudah mengetahui } \\
\text { bahwa AUM PTSDL salah satu } \\
\text { instrumen yang dapat digunakan } \\
\text { untuk melakukan need assessment pada } \\
\text { siswa sudah mengetahui bahwa AUM } \\
\text { PTSDL bisa diolah secara } \\
\text { komputerisasi namun belum mengerti } \\
\text { bagaimana caranya }\end{array}$ & $\begin{array}{l}\text { Memahami dan mampu } \\
\text { mempraktikkan } \quad \text { cara } \\
\text { pengolahan AUM PTSDL } \\
\text { menggunakan aplikasi } \\
\text { komputer. }\end{array}$ \\
\hline
\end{tabular}

\section{KESIMPULAN}

Berdasarkan hasil pelaksanaan pelatihan aplikasi AUM PTSDL yang sudah dilakukan dapat diambil kesimpulan sebagai berikut: Guru BK SMP Negeri 17 Depok memiliki pengetahuan dan kemampuan dalam menggunakan aplikasi komputer dalam pengolahan AUM PTSDL. Dengan kata lain, mampu mempraktikkan pengolahan hasil AUM PTSDL menggunakan aplikasi komputerisasi.

\section{UCAPAN TERIMAKASIH}

Tim pengabdian masyarakat mengucapkan terima kasih kepada Kepala sekolah, Koordinator Guru BK dan Guru BK SMP N 17 Depok yang telah mengizinkan, memfasilitasi kami dalam melakukan pengabdian masyarakat. Selanjutnya kepada Vio Hernawati selaku MC dan Ibu Hayu Stevani, M.Pd. Selaku moderator, terima kasih sudah meluangkan waktunya untuk membantu kegiatan tim abdimas sehingga kegiatan abdimas berjalan dengan baik. 


\section{DAFTAR PUSTAKA}

Awaluddin, A. (2019). Penerapan metode tanya jawab dalam upaya meningkatkan mutu belajar agama islam pada siswa SD kelas Vi Gelangsar lombok barat. JUPE: Jurnal Pendidikan Mandala, 4(5).

Evianti, N., Subekti, R., \& Firmansyah, B. (2020). Pelatihan Pengolahan Alat Ungkap Masalah (Aum) Dengan Menggunakan Komputer Bagi Konselor Sekolah Smkn 62 Lenteng Agung. Jurnal Pengabdian Teratai, 1(2), 303-307.

Gibson, R. L., \& Mitchell, M. H. (2008). Introduction to Counseling and Guidance. Pearson Prentice Hall.

Hatch, K. D., \& McCarthy, C. J. (2003). Challenge course participation as a component of experiential groups for counselors in training. Journal for Specialists in Group Work, 28(3), 199-214.

Hussain, A., Azeem, M., \& Shakoor, A. (2011). Physics teaching methods: scientific inquiry vs traditional lecture. International Journal of Humanities and Social Science, 1(19), 269-276.

Ifdil, I., Ilyas, A., Churnia, E., Erwinda, L., Zola, N., Fadli, R. P., Sari, A., \& Refnadi, R. (2017). Pengolahan Alat Ungkap Masalah (AUM) dengan Menggunakan Komputer Bagi Konselor. Jurnal Aplikasi IPTEK Indonesia, 1(1), 17-24.

Imawanty, \& Fransiska, A. B. (2019). Optimalisasi Asesmen dan Evaluasi Bimbingan dan Konseling Dengan Memanfaatkan Aplikasi Formulir Daring Jotform. Konvensi Nasional XXI Asosiasi Bimbingan dan Konseling Indonesia (pp. 129-135). Bandung: PB ABKIN.

Kemendikbud. (2020). Surat Edaran Nomor 3 Tahun $202 O$ Tentang Pencegahan Corona Virus Disase (COVID-19) Pada Satuan Pendidikan.

Komalasari, G., \& Wahyuni, E. (2011). Asesmen Teknik Nontes dalam Perspektif BK Komprehensif. Jakarta: PT Indeks.

Lestari, T., Wujoso, H., \& Suryani, N. (2017). Pengaruh Metode Pembelajaran Ceramah Plus dan Metode Drill terhadap Motivasi Belajar dan Hasil Belajar pada Kompentensi Dasar Efisiensi penggunaan Tempat Tidur Rumah Sakit. Media Ilmu Keolahragaan Indonesia, 7(1), 16-23.

Mukhlison. (2020). Kendala Pembelajaran Jarak Jauh Dan Solusinya. https://www.stitalkifayahriau.ac.id/kendala-pembelajaran-jarak-jauh-dan-solusinya/

Saman, A., Umar, N. F., \& Bakhtiar, M. I. (2020). Asesmen Online Bagi Guru Bimbingan Dan Konseling Kabupaten Barru. Seminar Nasional Pengabdian Kepada Masyarakat, 1(2). http://103.76.50.195/semnaslpm/article/view/15811

Stevani, H., Andriani, R., \& Fijriani, F. (2019). Analis is Kondisi Psikologis Sis wa Serta Implikasinya Terhadap Program Bimbingan Dan Konseling. ENLIGHTEN: Jurnal Bimbingan Konseling Islam, 2(2), 62-67.

Sukma Hanggara, G., Andrianie, S., \& Dwi Ariyanto, R. (2018). Penggunaan Aplikasi Analisis Kebutuhan Berbasis SMS untuk Optimalisasi Layanan BK dalam Memfasilitasi Perkembangan Siswa Seutuhnya. UPH Press. http://dspace.uphsurabaya.ac.id:8080/xmlui/handle/123456789/1208

Tere, M. I., \& Herdi, H. (2021). Asesmen Kebutuhan Sebagai Dasar Perencanaan Program Bimbingan Pribadi Berbasis Multikultural DI SMA. Jurnal Bimbingan Dan Konseling Terapan, 5(1), 25-29. 